\title{
EFEKTIFITAS PROMOSI DALAM PENINGKATAN PENJUALAN PRODUK KOSMETIK DI KOTA BLITAR
}

Denok Wahyudi Setyo Rahayu

Fakultas Ekonomi Universitas Islam Balitar Blitar emal: denok.wahyudisr@gmail.com

\section{Kata kunci:}

Produk, promosi, media iklan, konsumen.

\section{Keywords:}

Product, promotion, adevertising, consumer

$\begin{array}{lll}\text { Denok Wahyudi } & \text { Setyo } \\ \text { Rahayu } & \end{array}$

(2019). Efektifitas Promosi Dalam Peningkatan Penjualan Produk Kosmetik di Kota Blitar.

Akuntabilitas: Jurnal Ilmu-Ilmu Ekonomi, 12(1), 46-57.

https://doi.org/10.35457/akuntabi litas.v12i1.720

\begin{abstract}
ABSTRAK
Pemasaran merupakan hal penting dalam penjualan produk. Penggunaan promosi sebagai penunjang penjualan. Media iklan merupakan salah satu kegiatan promosi. Penelitian ini bertujuan untuk mengetahui efektifitas promosi yaitu iklan dalam meningkatkan penjualan produk di toko kosmetik Kota Blitar. Responden penelitian adalah pembeli produk kosmetik di Kota Blitar. Metode penelitian dengan menggunakan pengamatan dan wawancara secara langsung kepada responden dengan accidental sampling. Hasil penelitian menunjukkan promosi efektif dalam mempengaruhi konsumen untuk membeli produk kosmetik sehingga dapat meningkatkan penjualan produk kosmetik di Kota Blitar.
\end{abstract}

\section{ABSTRACT}

Marketing is very important at product sales. Promotions support sales. Advertising is promotional activities. Purpose research is effectiveness of promotion as advertising to increasing sales product of cosmetics in Blitar city. The method is observation and direct interview with respondent by accidental sampling. The result is effective promotion in influencing consumer to buying it, so increase sale of cosmetics in the Blitar city.

\section{PENDAHULUAN}

Pemasaran merupakan hal penting dalam penjualan produk. Metode pemasaran yang baik dapat memberikan dampak positif bagi perusahaan. Peningkatan profit perusahaan merupakan salah satu hasil positif dari metode pemasaran yang baik. Kotler (Ginting, 2015 :15) menyatakan pemasaran sebagai suatu proses sosial dan manajerial pada individu maupun kelompok dalam 
memperoleh suatu yang diinginkan dan dibutuhkan melalui penciptaan, penawaran maupun menukar produk yang bernilai dengan orang lain. Maynard dan Beckman menyatakan pemasaran sebagai segala usaha yang meliputi penyaluran barang dan jasa dari sektor produksi ke sektor konsumsi (Alma, 2005 : 1). Pemasaran digunakan produsen untuk menyalurkan atau memindahtangankan produk yang dihasilkan kepada konsumen. Produk tersebut merupakan produk yang diproduksi dalam rangka memenuhi kebutuhan dan harapan konsumen. Pemenuhan tersebut dapat menciptakan pola pandang positif konsumen terhadap produsen.

Pada dasarnya produk yang dihasilkan produsen dapat tersalurkan kepada konsumen dengan berbagai cara. Salah satunya adalah promosi. Dalam kegiatan pemasaran dibutuhkan promosi untuk meningkatkan penjualan. Penggunaan promosi merupakan langkah yang dapat dilakukan dalam memperkenalkan produk kepada konsumen. Keberadaan promosi dapat menunjang persepsi positif masyarakat selaku calon konsumen. Promosi yang baik akan berdampak positif. Promosi merupakan suatu unsur yang digunakan untuk memberitahukan dan membujuk pasar tentang produk atau jasa yang baru pada perusahaan melalui iklan, penjualan pribadi, promosi penjualan, maupun publikasi (Kotler dan Armstrong, 2012:62). Promosi sebagai fungsi komunikasi perusahaan yang bertanggungjawab memberi informasi dan membujuk atau mengajak pembeli (Babin, 2011:27). Komunikasi yang baik dalam promosi diharapkan dapat menjadi dasar menarik minat konsumen membeli produk tersebut. Ketertarikan konsumen pada produk menjadi harapan produsen sehingga produk dapat terjual. Semakin banyak produk terjual, maka keuntungan produsen akan semakin besar. Dalam promosi, penggunaan media harus dipilih dengan tepat. Ketepatan tersebut dapat menarik konsumen untuk mengkonsumsi produk. Penggunaan model iklan untuk TV maupun surat kabar, media sosial, tampilan katalog dan website perusahaan selaku produsen juga harus tepat.

Terdapat elemen promosi yang dikemukana oleh Kotler dan Armstrong (Alma, 2005, 181), yaitu : (1) adverstising (periklanan), (2) sales promotion (promosi penjualan), (3) public relation (hubungan masyarakat), dan (4) personal selling (penjualan personal). Elemen promosi tersebut digunakan untuk menarik minat Efektifitas Promosi Dalam Peningkatan Penjualan Produk Kosmetik di Kota Blitar https:// doi.org/10.35457/akuntabilitas.v12i1.720 

produknya dapat terjual. Semakin banyak yang terjual maka dapat memberikan keuntungan bagi perusahaan selaku produsen produk tersebut.

Burke menyatakan periklanan merupakan kegiatan penyampaian pesanpesan penjualan yang diarahkan kepada masyarakat melalui cara-cara yang persuasif yang bertujuan menjual barang, jasa, atau ide (Alma, 2005 : 182), sedang Swastha (2002 : 248) menyatakan sebagai suatu alat untuk membuka komunikasi dua arah antara penjual dengan pembeli, sehingga keinginan mereka dapat terpenuhi dengan cara yang efisien dan efektif. Iklan merupakan semua bentuk aktifitas untuk menghadirkan dan mempromosikan ide, barang, atau jasa secara non personal yang dibayar oleh sponsor tertentu (Durianto, 2004). Promosi penjualan merupakan insentif yang dirancang untuk mendorong pembelian atau penjualan sebuah produk - biasanya untuk jangka pendek, misal : kupon, sayembara, perlombaan, sampel produk, rabat, pertalian, premi langsung cair, pertunjukkan dagang, tukar-tambah, dan pameran (Boyd et al, 2000:66). Ruslan (2006:245) menyatakan marketing public relation sebagai sebuah proses perencanaan dan pengevaluasian program-program yang dapat merangsang penjualan dan pelanggan. Penjualan personal adalah komunikasi langsung (tatap muka) antara penjual dan calon pelanggan untuk memperkenalkan suatu produk kepada calon pelanggan dan membentuk pemahaman pelanggan terhadap produk sehingga mereka kemudian akan mencoba dan membelinya (Tjiptono, 2008). Berbagai cara promosi dapat dilakukan salah satunya dengan penggunaan iklan dengan memberikan tampilan yang menarik.

Iklan sebagai komunikasi bersifat komersil tentang sebuah organisasi atau perusahaan sehingga produk dapat tersampaikan kepada konsumen. Media iklan dapat berupa majalah, surat kabar, TV, radio, papan reklame, dan lain-lain. Media tersebut digunakan produsen untuk memperkenalkan produk-produk yang dihasilkan. Pelanggan akan mengetahui produk melalui media iklan tersebut.

Produk kosmetik merupakan produk yang banyak diminati konsumen. Industri kosmetik nasional mencatat kenaikan pertumbuhan $20 \%$ atau empat kali lipat dari pertumbuhan ekonomi nasional pada tahun 2017 (www.kemenperin.go.id). Pertumbuhan produk kosmetik nasional memberi 
gambaran bagi produsen untuk kreatif dalam memasarkan produk supaya dapat bersaing di pasar kosmetik. Kreatifitas dalam bentuk inovasi merupakan langkah perusahaan kosmetik untuk dapat bertahan dalam persaingan. Tanpa inovasi, produk kosmetik akan tergerus dan ditinggalkan oleh pembeli. Adakalanya produsen kosmetik selain melakukan inovasi juga melakukan pembuatan produk baru untuk tampil beda dibanding pesaing.

Produk kosmetik menjadi salah satu produk di pasar yang sering menggunakan promosi berbetuk periklanan dalam memperkenalkan produknya. Tanpa promosi, inovasi produk maupun pembuatan produk baru tidak akan berarti. Promosi dapat memberi gambaran kepada calon konsumen mengenai produk kosmetik. Berbagai cara promosi dilakukan seperti iklan TV yang menarik, pembuatan katalog, membuat tampilan website yang menarik dengan mengupas tentang produk dan sebagainya. Hal tersebut dilakukan untuk memperkenalkan produk-produk yang dihasilkan kepada para calon konsumen. Semakin menarik cara promosi yang dilakukan, diharapkan konsumen akan semakin tertarik untuk mengkonsumsinya. Promosi yang menarik minat beli konsumen dapat meningkatkan penjualan produk.

Pada saat ini, di Kota Blitar terdapat beberapa toko penjualan kosmetik. Toko tersebut menjual berbagai jenis kosmetik dengan merek-merek yang sudah dikenal oleh masyarakat, seperti Wardah, Make Over, Maybelline, Emina, Sariayu, La Tulipe, Viva dan lain sebagainya. Demikian beragam merek di pasar dapat menjadi pilihan bagi konsumen. Untuk memudahkan konsumen, maka produsen kosmetik menggunakan promosi sebagai sarana penarik konsumen, salah satunya dengan menggunakan media iklan. Iklan dilakukan untuk mendekatkan konsumen pada produk. Tampilan iklan yang menarik dapat meningkatkan minat beli bagi konsumen. Keberagaman produk menjadi pemicu penggunaan media iklan.

Pada penelitian ini bertujuan untuk mengetahui bagaimana efektifitas promosi dalam hal ini iklan dalam meningkatkan penjualan produk di toko kosmetik Kota Blitar. Tujuan tersebut menjadi acuan peneliti dalam mengetahui respon pembeli dengan adanya promosi yang dimaksud. 
Penelitian ini menggunakan beberapa penelitian terdahulu sebagai kajian, antara lain :

a. Budi Prasetyo dan Yunita Rismawati (2018), dengan judul : Pengaruh promosi penjualan terhadap keputusan pembelian pada PT Harjagunatama Lestari (Toserba Borma) Cabang Dakota. Tujuan penelitian : untuk mengetahui kondisi promosi penjualan, keputusan pembelian, dan besar pengaruh promosi penjualan terhadap keputuasan pembelian. Hasil penelitian menunjukkan bahwa pada promosi penjualan terdapat indikasi kelemahan pada variabel promosi penjualan khususnya pada alat insentif yang ditawarkan, untuk keputusan pembelian cukup baik, dan terdapat pengaruh promosi penjualan pada PT Harjagunatama Lestari (Toserba Borma) Cabang Dakota.

b. Denny Daud (2013), dengan judul : Promosi dan kualitas layanan pengaruhya terhadap keputusan konsumen menggunakan jasa pembiayaan pada PT. Bess Finance Manado. Tujuan penelitian : mengetahui pengaruh promosi dan kualitas layanan terhadap keputusan pembelian. Hasil penelitian menunjukkan bahwa promosi dan kualitas berpengaruh terhadap keputusan pembelian baik secara simultan maupun parsial.

c. Miftahur Rohmah (2018), dengan judul : Pengaruh promosi penjualan terhadap keputusan pembelian konsumen pada situs jual beli online Elevenia.Tujuan penelitian: untuk mengetahui pengaruh penjualan terhadap keputusan pembelian. Hasil penelitian menunjukkan stimulus berupa promosi penjualan yang diadakan oleh Elevania tidak memiliki pengaruh yang kuat, namun responden tetap memhami dan memperhatikn setiap promosi penjaulan yang dlakukan oleh situs Elevania.

\section{METODE PENELITIAN}

Metode yang digunakan dalam penelitian adalah menggunakan teknik pengamatan dan wawancara kepada konsumen toko kosmetik di Kota Blitar. Populasi penelitian adalah pembeli kosmetik dengan sampel menggunakan accidental sampling yaitu siapa saja yang secara kebetulan bertemu dengan peneliti., 
dengan waktu penelitian pada bulan Februari 2019. Lokasi penelitian di toko Kosmetik Kota Blitar. Variabel penelitian yang digunakan adalah periklanan atau media iklan yang merupakan suatu alat untuk memberikan informasi kepada pembeli dalam rangka memenuhi harapan pembeli, dengan indikator TV, beauty vloger, katalog, dan website.

\section{Gambar 1.}

\section{Kerangka Konseptual Penelitian}

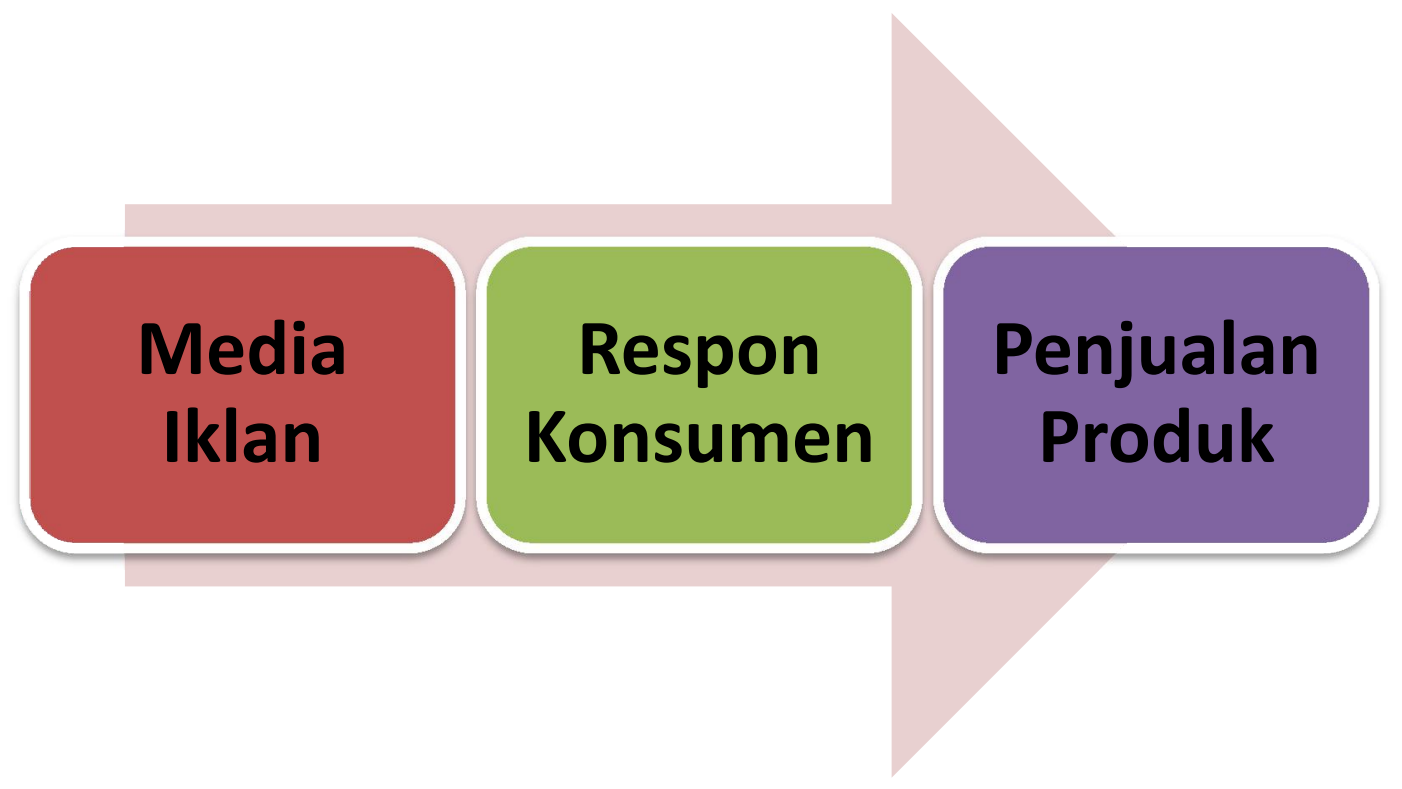

Gambar 1 merupakan konsep penelitian yaitu media iklan yang digunakan oleh produsen kosmetik yang dilanjutkan pada respon konsumen berkenaan dengan produk yang diiklankan kemudian pada tingkat penjualan produk setelah terdapat respon konsumen dari media iklan yang tersaji. Respon konsumen dapat diketahui berdasarkan perilaku setelah melalui media iklan, yaitu membeli atau tidak membeli kosmetik yang diiklankan. Penjualan produk akan meningkat bilamana responden selaku konsumen membeli produk kosmetik tersebut. Media iklan menggunakan indikator TV, beauty vloger, katalog, dan website. Berdasarkan indikator tersebut pada dasarnya akan dikaji media iklan mana yang paling dominan dalam menarik minat konsumen dalam bentuk respon positif yang akan membeli produk kosmetik. 
Respon akan mengarah pada pembelian yang akan berujung pada peningkatan penjualan produk kosmetik.

Alur penelitian yang digunakan adalah pengumpulan data, teknis analisis data, dan hasil. Pada pengumpulan data dilakukan dengan cara melakukan wawancara dengan pembeli kosmetik selaku responden penelitian dan juga pengamatan secara langsung terhadap perilaku pembeli. Wawancara yang dilakukan dengan menanyakan tentang bagiamana responden mengetahui produk kosmetik tersebut berikut alasannya kenapa memilih produk tersebut. Untuk pengamatan langsung dengan cara mengamati perilaku pembeli dalam menentukan pilihan produk yang terkadang disertai komunikasi dengan penjual tentang pengetahuan produk yang akan dibeli dan darimana responden mengetahui produk tersebut.

Menurut Miles dan Huberman dalam teknis analisis data menggunakan 3 tahapan yaitu reduksi data, penyajian data, dan penarikan kesimpulan (Basrowi dan Suwandi, 2008). Reduksi data merupakan proses pemilihan, pemusatan perhatian untuk penyederhanaan, penggunaan abstrak dan melakukan transformasi data kasar dari lapangan. Penyajian data merupakan sekumpulan informasi disusun untuk memberikan kemungkinan dalam menarik kesimpulan serta mengambil tindakan. Menarik kesimpulan sebagai satu kegiatan dari konfigurasi yang utuh.

Hasil penelitian diperoleh setelah melalui proses teknis analisis data. Pada hasil penelitian akan diketahui bagaimana kesimpulan dari kegiatan penelitian yang dilakukan yang berhubungan dengan tujuan penelitian. 


\section{Gambar 2.}

\section{Alur Penelitian}

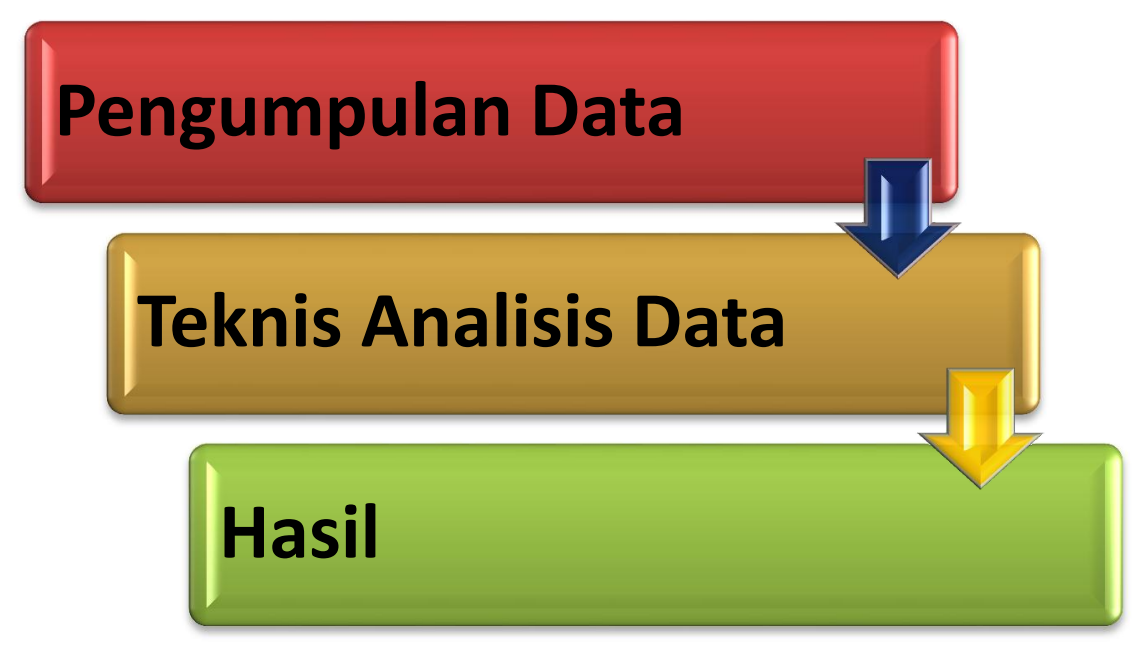

\section{PEMBAHASAN}

Iklan merupakan semua bentuk aktifitas untuk menghadirkan dan mempromosikan ide, barang, atau jasa secara non personal yang dibayar oleh sponsor tertentu (Durianto, 2004). Aktifitas yang dilakukan diharapkan dapat mempengaruhi pola pikir dari konsumen. Pada variabel media iklan dengan indikator TV, media sosial Youtube, katalog, dan website, didapatkan hasil bahwa semua media tersebut memberi pengaruh pada konsumen untuk melihat, mengenali, mencoba, dan bahkan membeli produk kosmetik tersebut. Ketertarikan responden pada produk kosmetik adalah berdasarkan bentuk iklan yang menurut responden menarik baik dari segi tampilan, bahasa, model iklan, dan suasana.

Mulanya konsumen mengetahui produk kosmetik melalui TV. Media iklan TV cenderung memegang peranan utama bagi konsumen untuk mengetahui produk secara mendalam. Penggunaan model iklan, tampilan, bahasa, dan suasana iklan memberikan efek positif bagi produk kosmetik tersebut. Konsumen dapat melihat jelas produk kosmetik yang ditampilkan. Media TV menjadi nilai utama dalam mempengaruh konsumen untuk mengetahui produk kosmetik. Konsumen sangat tertarik dengan iklan melalui TV. Pada dasarnya TV digunakan konsumen untuk mendapatkan hiburan sehari-hari. Tayangan TV yang bervariasi memberikan 
kemudahan iklan untuk tampil dalam setiap jeda program TV. Iklan menjadi lebih sering dilihat oleh konsumen. Semakin sering ditayangkan akan memberi rekaman berulang di pikiran konsumen. Kosmetik yang diiklankan pada setiap jeda program membuat konsumen penasaran untuk mengetahui bila kosmetik tersebut masih baru diluncurkan dan akan memberi efek matang pada pikiran konsumen bila kosmetik tersebut bukan produk baru.

Pengenalan produk kosmetik melalui TV dapat merangsang keingintahuan konsumen. Semakin konsumen penasaran maka akan semakin konsumen ingin memiliki kosmetik tersebut. Daya tarik iklan TV dapat terukur dari penggunaan model iklan serta tampilan. Model iklan yang digunakan dapat memberi efek bagi konsumen yang melihat untuk mengenal produk kosmetik lebih dekat. Semakin terkenal model iklan, semakin konsumen tertarik untuk mencoba produk. Kecenderungan TV menjadi media yang lebih produktif dalam mempengaruhi konsumen untuk mengetahui produk yang ditayangkan. Rasa ingin tahu konsumen akan terobati bila produk yang dimaksud telah tersedia. Ketersediaan produk dapat membuat konsumen untuk membeli produk.

Gambar 3.

Urutan Pilihan Responden

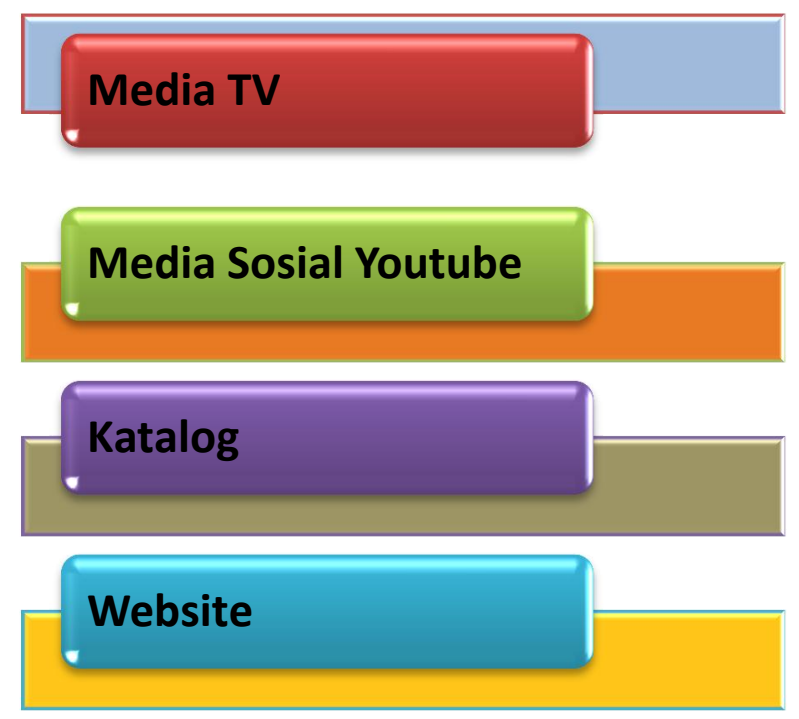

Keterbatasan waktu dalam penayangan iklan membuat konsumen kurang puas dengan informasi yang diberikan. Kemungkinan media TV dalam menampilkan iklan kurang terperinci. Selanjutkan konsumen mencari informasi 
Melalui media sosial tersebut, konsumen dapat mengetahui secara jelas tentang penilaian dan juga hasil dari penggunaan kosmetik. Beberapa beauty vloger akan mengulas tentang bagaimana penggunaan, harga, respon terhadap produk. Pernyataan-pernyaan yang disampaikan akan memberi pengaruh bagi konsumen dalam memberi keputusan. Penilaian tersebut terperinci dan mendalam serta menyajikan hasil dari pemakaian kosmetik. Selanjutnya, terdapat pula tanggapan dari pemerhati youtube mengenai unggahan tersebut. Dialog yang terjadi menjadi kajian lanjutan konsumen. Hal tersebut memberi dampak pada konsumen untuk membeli atau tidak kosmetik yang dibahas. Konsumen merasa penilaian tersebut dapat menjadi acuan antara membeli atau tidak kosmetik tersebut.

Posisi katalog dan website menjadi acuan konsumen selanjutnya unuk mengetahui detail produk kosmetik berikut bentuk, warna, dan varian. Keberagaman tersebut dapat memberi gambaran bagi konsumen untuk menentukan pilihan kosmetik yang diinginkan. Katalog dan website dapat memberi informasi pada konsumen tentang jenis kosmetik yang diproduksi berikut detail perusahaan.

Pada katalog terdapat model produk baik dari segi bentuk, warna, varian dan sebagainya. Keberadaan katalog sangat membatu konsumen untuk menentukan produk mana yang akan dibeli. Katalog tersaji pada etalase-etalase toko kosmetik. Konsumen yang datang dapat mengambil untuk sekedar melihat dan membaca, namun ada pula yang selanjutnya membeli produk. Keberadaan katalog memudahkan konsumen bila terdapat produk baru yang belum mereka ketahui.

Website mengulas produk kosmetik untuk memberi pengetahuan pada konsumen mengenai produk kosmetik yang tersaji. Pada tampilan website, akan terlihat varian produk yang dihasilkan berikut keterangan jelas mengenai produk. Hal tersebut memberi kemudahan pada konsumen dalam memahami produk. Selain itu website memberi informasi berkenaan dengan perusahaan selaku produsen kosmetik. Informasi mengenai lokasi, produksi, kualitas perusahaan dan sebagainya yang dapat meyakinkan konsumen akan kualitas produk kosmetik.

Pemasaran yang dilakukan produsen kosmetik merupakan langkah yang baik untuk memindahkan produk ke tangan konsumen. Penggunaan media iklan seperti Efektifitas Promosi Dalam Peningkatan Penjualan Produk Kosmetik di Kota Blitar https:// doi.org/10.35457/akuntabilitas.v12i1.720 
TV, media sosial Youtube, katalog, dan website. Media iklan tersebut dapat diterima dan dipahami oleh konsumen. Tampilan iklan, bahasa, model iklan, dan suasana pembuatan iklan menjadi hal penting yang dapat menarik minat konsumen untuk mengetahui, mencoba, bahkan membeli kosmetik tersebut. Ketertarikan konsumen akan memberi dampak pada pembelian produk. Semakin banyak produk terjual maka akan meningkatkan penjualan. Media iklan dapat merangsang konsumen untuk melakukan pembelian. Keefektifan promosi dalam kaitannya dengan media iklan yang digunakan dapat meningkatkan penjualan produk kosmetik di Kota Blitar.

Berdasarkan ulasan tersebut dapat diketahui promosi dengan menggunakan media iklan efektif dalam meningkatkan penjualan kosmetik di Kota Blitar. Hasil penelitian mendukung dari penelitian Denny Daud (2013) mengenai promosi yang berpengaruh terhadap keputusan pembelian, Budi Prasetyo dan Yunita Rismawati (2018) mengenai kelemahan variabel promosi serta Miftahur Rohmah (2018) mengenai promosi penjualan yang tidak memiliki pengaruh yang kuat. Hasil dari penelitian Budi Prasetyo dan Yunita Rismawati (2018) serta Miftahur Rohmah (2018) promosi tetap berpengaruh meski nilainya kecil. Promosi yang efektif dapat meningkatkan penjualan produk kosmetik. Keefektifan promosi dapat diukur melalui respon konsumen setelah melihat atau memahami media iklan. Konsumen yang merespon positif media iklan akan melakukan pembelanjaan kosmetik tersebut, sehingga hal tersebut dapat meningkatkan penjualan kosmetik bagi perusahaan selaku produsen.

\section{KESIMPULAN}

Media iklan merupakan sarana promosi yang efektif untuk meningkatkan penjualan kosmetik di Kota Blitar. Indikator yang digunakan adalah TV, media sosial Youtube, katalog, dan website. Posisi media iklan melalui TV memegang peranan utama dalam mempengaruhi konsumen. Media iklan TV menjadi posisi utama karena merupakan sarana hiburan yang sering dilihat oleh konsumen sehingga tertanam di benak konsumen. Indikator media sosial Youtube menjadi indikator selanjutnya yang mempengaruhi konsumen untuk membeli atau tidak membeli 

konsumen untuk memahami produk kosmetik tersebut.

Media iklan merupakan sarana efektif dalam meningkatkan penjualan kosmetik. Beragam produk kosmetik beredar di pasar. Berbagai varian produk kosmetik yang beredar membuat produsen kosmetik untuk menggunakan media iklan. Ketertarikan konsumen dapat dimulai dari iklan yang menarik. Tampilan iklan secara visual di TV dapat menjadi cara mempengaruhi pola pikir konsumen untuk membeli produk. Penggunaan media sosial Youtube sebagai langkah yang dapat digunakan pula. Youtube menampilan penggunakan produk secara terperinci berikut ulasan. Katalog dengan tampilan menarik dapat menjadi daya tarik konsumen. Selanjutnya, website wajib dimiliki produsen yang memuat ulasan produk berikut profil perusahaan.

Sebaiknya pihak produsen selalu membuat iklan yang menarik untuk konsumen dari waktu ke waktu. Iklan yang tidak diperbaruhi akan memberikan kebosanan bagi konsumen. Keterbaruan iklan dapat memberi nilai positif sehingga dapat menarik konsumen untuk membeli produk kosmetik. Keterbaruan tersebut dapat menggunakan bintang iklan yang sedang bersinar, tampilan warna iklan sesuai perkembangan jaman dan sasaran konsumen serta tampilan berupa kemasan kosmetik yang mengikuti perkembangan jaman.

\section{DAFTAR PUSTAKA}

Alma, Buchari. 2005. Manajemen Pemasaran dan Pemasaran Jasa. Bandung : Alfabeta.

Babin, Zikmund. 2011. Menjelajahi Riset Pemasaran. Edisi Kesepuluh. Jakarta : Salemba Empat.

Basrowi dan Suwandi. 2008. Memahami Penelitian Kualitatif.Jakarta : PT Rineka Cipta.

Boyd, Harper W, Orville C, Walker dan Jean Claude Larreche. 2000. Manajemen Pemasaran. Terjemahan Imam Nurmawan. Jakarta : Erlangga.

Ginting, Nembah F. Hartimbul. 2011. Manajemen Pemasaran. Bandung : CV. Yrama Widya. 
Kotler, P., \& Armstrong, G. 2012. Principles of marketing: global edition (14th ed.). New Jersey, US: Pearson Education, Inc.

Prasetyo, Budi dan Yunita Rismawati. 2018. Pengaruh Promosi Penjualan Terhadap Keputusan Pembelian Pada PT Harjagunatama Lestari (Toserba Borma) Cabang Dakota. Jurnal Ilmiah Manajemen Ekonomi dan Akuntansi. Vol. 2 No. 2 Januari - Juni 2018. Halaman 57 sd 65.

Miftahur Rohmah. 2018. Pengaruh Promosi Penjualan Terhadap Keputusan Pembelian Konsumen Pada Situs Jual Beli Online Elevenia. JOM FISIP. Vol. 5 : Edisi II Juli - Desember 2018. Halaman 1 sd 13.

Ruslan, R. 2006. Manajemen Public Relation dan Media Komunikasi : Konsepsi dan Aplikasi. Jakarta : Raja Grafindo Persada.

Swastha, Basu. 2002. Manajemen Pemasaran. Edisi Kedua. Cetakan Kedelapan. Jaskarta : Liberty.

Tjiptono, F. 2008. Strategi Pemasaran. Yogyakarta : ANDI.

www.kemenperin.go.id sumber : Investor Daily (20/03/2018). 